Niepełnosprawność. Dyskursy pedagogiki specjalnej

Nr 24/2016

Disability. Discourses of special education

No. $24 / 2016$

Monika Gołubiew-Konieczna

PSOUU koło w Gdańsku

\title{
Wspieranie osób z głębszą i głęboką niepełnosprawnością intelektualną i ich rodziców w drodze przez całe życie na przykładzie działalności Polskiego Stowarzyszenia na rzecz Osób z Upośledzeniem Umysłowym ${ }^{1}$, koło w Gdańsku
}

\section{Lifelong support for people with moderate, severe and profo und intellectual disabilities and their parents. (an example from the Polish Association for Persons with Mental Handicap - the branch in Gdańsk)}

The article points out the necessity of a lifelong support for people with moderate, severe and profound intellectual disability and their parents. The first part of the article is a theoretical approach to highlight and argument the importance of a support. The second part is a presentation of the Polish Association for Persons with Mental Handicap- the branch in Gdańsk whose institutions and long- term programs serve as an important tool to prove lifelong support is possible.

Słowa kluczowe: głęboka i głębsza niepełnosprawność intelektualna, całożyciowe wsparcie, Polskie Stowarzyszenia na rzecz Osób z Upośledzeniem Umysłowym

Keywords: moderate, severe and profound intellectual disability, lifelong support, Polish Association for Persons with Mental Handicap

\section{Wprowadzenie}

Niniejszy artykuł poświęcony jest konieczności zapewnienia stosownego wsparcia osobom z głębszą i głęboką niepełnosprawnością intelektualną oraz ich

1 W dniu 19 września 2015 r. nadzwyczajny zjazd elektorów Polskiego Stowarzyszenia na rzecz Osób z Upośledzeniem Umysłowym uchwalił zmianę nazwy na Polskie Stowarzyszenie na rzecz Osób z Niepełnosprawnością Intelektualną, która obowiązuje także koło w Gdańsku od września 2016 r. Ponieważ niniejszy artykuł opisuje 50-letnią działalność koła, pozostano przy „starej” nazwie. 
rodzicom w drodze przez całe życie. W pierwszej części artykułu autorka od strony teoretycznej wskazuje na powody, dlaczego to wsparcie jest niezbędne, $w$ drugiej - prezentuje prowadzone przez Polskie Stowarzyszenie na rzecz Osób z Upośledzeniem Umysłowym koło w Gdańsku placówki i wieloletnie programy jako dowód, że jest to możliwe.

Niepełnosprawność intelektualna stwierdzana jest badaniem psychologicznym, przeprowadzanym $\mathrm{z}$ wykorzystaniem specjalnych testów, a wyrażana w tzw. ilorazie inteligencji (II) (Lausch-Żuk 2001, s. 149). Przyjęto, że osoby z głębszą niepełnosprawnością intelektualną (w stopniu umiarkowanym i znacznym) uzyskują wyniki ilorazu inteligencji poniżej 50, zaś osoby określane jako głęboko niepełnosprawne intelektualnie - poniżej 20 (ICD-10 2009, s. 244-245), co de facto oznacza, że ich sprawność umysłowa w sposób istotny odbiega „in minus” od przyjętych norm. Niepełnosprawność intelektualna, szczególnie osób w stopniu głębszym i głębokim utrudnia im przystosowanie się do wymogów środowiska, gdyż dotyczy nie tylko sfery intelektualnej, czyli orientacyjno-poznawczej (od niedokładnego spostrzegania, uwagi mimowolnej, wąskiego zakresu pamięci, myślenia konkretno-obrazowego, trudności w tworzeniu pojęć abstrakcyjnych, mowie z ubogim słownictwem i zaburzoną artykulacją osób z umiarkowaną niepełnosprawnością, po brak percepcji, mimowolnej i wybiórczej uwadze, braku myślenia logicznego, komunikowaniu się często poprzez nieartykułowane dźwięki osób z głęboką niepełnosprawnością), ale i emocjonalno-motywacyjnej (od umiejętności sygnalizowania swoich potrzeb, słabej kontroli nad popędami, intuicyjnymi uczuciami moralnymi osób z umiarkowaną niepełnosprawnością, po eksponowanie prostych emocji zadowolenia i niezadowolenia, częste wahania nastroju osób z głęboką niepełnosprawnością) oraz społecznej (od samodzielności w samoobsłudze, widocznej potrzebie kontaktów z innymi, umiejętnościami współpracy osób z umiarkowaną niepełnosprawnością, po prawie całkowity brak czynności regulacyjnych, brak możliwości samodzielnego dbania o własne bezpieczeństwo, wymogach stałej opieki pielęgnacyjnej osób z głęboką niepełnosprawnością) (Lausch-Żuk 2001, s. 150). Dodatkowo u osób tych najczęściej współwystępują inne schorzenia czy dysfunkcje rozwojowe (wady wzroku, słuchu, ruchu, zaburzenia psychiczne, choroby przewlekłe), co także pogłębia ich problemy w codziennym funkcjonowaniu.

Osoby z głębszą i głęboką niepełnosprawnością intelektualną tworzą bardzo zróżnicowaną grupę także ze względu na specyficzne kliniczne postacie tych niepełnosprawności (o zróżnicowanej etiologii) oraz cechy charakterologiczne, wynikające z naturalnych indywidualnych różnic zachodzących, po prostu, pomiędzy ludźmi. Niepełnosprawność intelektualna jest stanem, którego nie można wyeliminować, ale można, dzięki właściwym oddziaływaniom pedagogicznym, nauczyć osoby nim dotknięte „z tym żyć” (tamże, s. 149). Wymaga to jednak za- 
akceptowania ich i zapewnienia im pomocy, polegającej nie tylko na szeroko rozumianej edukacji i wychowaniu, ale także na stwarzaniu odpowiednich warunków codziennego funkcjonowania i rozwoju osobowości (struktury JA, która dokonuje się przez interakcję z otoczeniem społecznym) (Kościelska 2000, s. 206). Osoby niepełnosprawne potrzebują też skutecznej rehabilitacji, zróżnicowanej w zależności od swojego wieku i stopnia niesprawności, rozumianej jako usprawnianie wszystkich funkcji, by maksymalnie i wszechstronnie przystosować się do życia w społeczeństwie, osiągnąć jak najpełniejsze usamodzielnienie i móc samorealizować się przez podejmowanie różnych aktywności (Dykcik 2005, s. 225).

\section{Osoby z niepełnosprawnością intelektualną $\mathrm{w}$ stopniu głębszym i głębokim $w$ rodzinie}

„Dziecko przychodząc na świat uzyskuje prawo do przynależności, otrzymując w ten sposób swoje miejsce w rodzinie" (Jagieła 2007, s. 13). Dotyczy to także dziecka z niepełnosprawnością intelektualną, choć jego sytuacja psychologiczna u progu życia jest na ogół niekorzystna - nikt przecież takiego dziecka nie oczekiwał (Lausch-Żuk 2001, s. 153). Diagnoza o niepełnosprawności intelektualnej stawia przed rodzicami nowe i bardzo trudne zadania, $\mathrm{z}$ których pierwsze to pogodzenie się z nią i zaakceptowanie dziecka takim jakim jest.

Zdaniem M. Pisuli (1998, s. 48-87) rodzice dzieci niepełnosprawnych znajdują się w permanentnej sytuacji stresowej. Stres rodzicielski jest zdecydowanie największy u rodziców tych dzieci, u których współwystępuje kilka zaburzeń równocześnie oraz dodatkowo zaburzenia zachowania. Nasilenie stresu wzrasta w miarę dorastania dziecka, a szczególnie trudne chwile dla rodziców to tzw. okresy przejściowe pomiędzy kolejnymi fazami rozwoju - są one związane z dezorganizacją życia rodzinnego, koniecznością dokonywania kolejnych zmian w sposobie działania, podejmowania nowych decyzji i dostosowywania się do nowych potrzeb dziecka. Bardzo trudny okres to dorastanie, choć wydaje się, że największym problemem dla rodziców jest konieczności opieki nad dorosłymi już dziećmi, a więc bycie "wiecznym rodzicem", a także niezmienna troska o przyszłość "dorosłych dzieci”, gdy ich, czyli rodziców, „zabraknie” (Dykcik 2010, s. 170).

Problem niepełnosprawności dziecka to dla rodziny sytuacja kryzysowa, szczególnie wtedy, gdy uznają, że nie mają odpowiednich kompetencji i sił do radzenia sobie z licznymi problemami dnia codziennego (tamże, s. 179). Wydaje się, iż są jakby przytłoczeni odpowiedzialnością, bowiem „od samego początku zaistnienia niepełnosprawności dziecka zmuszeni są do nabywania specjalnych kompetencji poznawczych, interakcyjnych i sprawnościowych, aby w różnych sytuacjach mieć gwarancje skuteczności własnych działań oraz pełną gotowość do 
prawidłowego ich wypełniania jako akceptowanych ról rodzicielskich" (tamże, s. 38). Dlatego też „W procesie rozwoju, opiece, terapii, rehabilitacji oraz usamodzielniania dzieci z różnego rodzaju chorobami i kategoriami niepełnosprawności rodzina najczęściej nie jest i nie może być samowystarczalna" (Dykcik 2010, s. 163). M. Kościelska (2000, s. 94-95), na podstawie własnych doświadczeń, przedstawia listę potrzeb, których zaspokojenie $\mathrm{w}$ znacznym stopniu poprawiłoby sytuacje rodzin wychowujących dzieci z niepełnosprawnością intelektualną, a są to:

- akceptacja społeczna (specjaliści oczekują od rodziców zaakceptowania dziecka $\mathrm{w}$ jego niepełnosprawności, a rodzice potrzebują poczucia akceptacji otoczenia dla siebie i dzieci oraz dowodów tego w sposobie organizacji życia społecznego);

- dobre miejsce dla dzieci w systemie opieki, edukacji, rewalidacji (rodzice potrzebują miejsc, gdzie chciano by ich dzieci);

- pełna, prawdziwa i wyczerpująca informacja (rodzice potrzebują wiedzy o stanie swoich dzieci oraz o dostępnych specjalistycznych placówkach, książkach, stowarzyszeniach, skąd mogą otrzymać stosowną pomoc);

- specjalistyczna pomoc nakierowana na dziecko i jego rodziców (w zależności od stanu dziecka rodzice potrzebują dla dziecka psychoterapii, różnego rodzaju ćwiczeń edukacyjnych i terapeutycznych, zapewnienia właściwych warunków wychowawczych, dla siebie zaś, możliwego do wykonania, ukierunkowania do pracy $\mathrm{z}$ dzieckiem przy pełnym szacunku traktowania ich przez specjalistów);

- wspólnota (rodzice potrzebują grupy odniesienia dających poczucie więzi i oparcia, a także modelujących wzorce konstruktywnego radzenia sobie z sytuacją dnia codziennego lub występującą tzw. nagłą sytuacją trudną);

- ułatwiające życie usprawnienia techniczne (rodzice potrzebują zapewnienia możliwości kompensacji defektów przez różnego typu urządzenia techniczne, by poprawić jakość życia ich dzieciom) (tamże).

Ponadto na sytuację rodziców znaczący wpływ ma ich aktywność zawodowa, która nie tylko może poprawić status materialny (niepełnosprawność dziecka niestety łączy się z ponoszeniem wysokich kosztów leczenia i usprawniania), ale także ma wpływ na odnoszenie przez rodziców sukcesów w innych dziedzinach, poczucie spełnienia i realizacji własnych aspiracji, współdziałania z innymi ludźmi przy rozwiązywaniu problemów innych niż te, związane z wychowywaniem dziecka. Praca zawodowa pozwala bowiem na nabranie dystansu wobec problemów swojego dziecka i świeższe na nie spojrzenie, a czasem lepsze radzenie sobie w życiu codziennym pomimo dodatkowych obciążeń (Pisula, s. 82-85). Rodzice dzieci niepełnosprawnych nie powinni zamykać się $\mathrm{w}$ tzw. kręgu niepełnosprawności. B. Tylewska-Nowak (2010, s. 55) radzi: „Znajdź czas dla siebie, swojego hobby, pamiętaj, jeśli ty będzie zadowolony i radosny, przekażesz tę radość dziecku". 
A jak pisze W. Dykcik (2010, s. 389, za: M.E.P. Selligman 2005) „Pozytywne nastawienie do życia, jako proces regulacji psychicznej może spowodować, że nawet człowiek słaby, chory, niepełnosprawny...może zmienić swoją mentalność na aktywną, transgresyjną, poszukującą alternatywnych możliwości zaspokajania potrzeb, odmiennych zainteresowań i sposobów widzenia świata".

\section{Wspieranie osób z niepełnosprawnością intelektualną w stopniu głębszym i głębokim oraz ich rodziców przez PSOUU koło w Gdańsku}

Osoby z niepełnosprawnością intelektualną w stopniu głębszym i głębokim (bo o nich jest mowa w tym artykule), a także ich rodzice, potrzebują więc całożyciowego wsparcia, definiując to wsparcie jako możliwość skorzystania z pomocy w sytuacjach trudnych. A niewątpliwie taką było i jest życie oraz wychowywanie (zdecydowanie bardzo „rozciągniętego w czasie”) dziecka z niepełnosprawnością intelektualną. Dlatego też ponad 50 lat temu, z inicjatywy rodziców, powstało Polskie Stowarzyszenie na rzecz Osób z Upośledzeniem Umysłowym (PSOUU), które za swoją misję uznało: „Dbanie o godność ludzką, miejsce w rodzinie i wśród innych ludzi oraz szczęście osób niepełnosprawnych intelektualnie oraz wspieranie rodzin, aby były one wstanie sprostać sytuacjom, które pociąga za sobą fakt urodzenia dziecka z niepełnosprawnością i wspólne życie oraz przekształcać własny ból w gotowość niesienia pomocy innym" (www.psouu.org.pl). Zadania wynikające z ww. misji do dnia dzisiejszego PSOUU realizuje, między innymi, poprzez organizowanie i prowadzenie różnego rodzaju placówek, programów i usług dla niepełnosprawnych dzieci i osób dorosłych w zakresie kompleksowej, wielodyscyplinarnej rehabilitacji i terapii, edukacji, przygotowania do pracy, zatrudniania, opieki mieszkaniowej, rekreacji oraz wspierania w samodzielności, a także pomoc ich rodzinom. Jest to możliwe dzięki terenowym kołom, działającym już w 123 miejscowościach w Polsce (tamże).

Gdańskie koło PSOUU przez prowadzone przez siebie placówki i realizowane programy stworzyło system wsparcia osobom niepełnosprawnym intelektualnie i ich rodzinom, gwarantujący pomoc od narodzin dziecka z niepełnosprawnością, poprzez jego wiek szkolny, aż po dorosłość, oferując w szczególności wczesne wspomaganie rozwoju, wsparcie w edukacji dla dzieci znajdujących się w tzw. obowiązku szkolnym i obowiązku nauki, pomoc w przygotowaniu się do podjęcia pracy młodych dorosłych, znalezieniu jej i utrzymaniu, samodzielnym zamieszkaniu i prowadzeniu dziennej aktywności oraz w rozwijaniu zainteresowań i możliwości spędzania wolnego czasu w sposób twórczy. Można więc uznać, że tym samym spełnione zostały główne postulaty normalizacyjne, rozu- 
miane jako szereg „instytucjonalnych i pozainstytucjonalnych działań zmierzających do stworzenia normalnych warunków życia jednostkom upośledzonym umysłowo oraz udzielenie im takiej pomocy, by przez całe swoje życie mogli normalnie funkcjonować, tak jak to jest tylko możliwe" (Krause 2000, s. 24).

Założenia normalizacyjne, takie jak: mieszkanie w swoim domu, normalizacji rytmu dnia, normalizacji życiorysu, normalizacji autonomii, normalizacji warunków materialnej egzystencji, normalizacji kontaktów socjalnych i dostępu do kultury w środowisku lokalnym (tamże, s. 131-135), zostały wdrożone nie tylko w odniesieniu do osób z niepełnosprawnością intelektualną, ale także do ich rodziców - wspierając w różny sposób dzieci na drodze życia, zapewniono także rodzicom możliwość „normalnego" funkcjonowania i pełnienia różnych ról rodzicielskich (charakterystycznych dla młodych rodziców, rodziców dzieci w wieku szkolnym, rodziców młodych dorosłych, rodziców dorosłych dzieci, które opuściły dom rodzinny i rozpoczęly samodzielne życie prowadząc własne gospodarstwo domowe, pracując i rozwijając zainteresowania), przy jednoczesnym kontynuowaniu własnej zawodowej kariery. Tym samym PSOUU koło w Gdańsku spełnia swoje zadanie, sformułowane jako: „Działanie na rzecz wyrównywania szans osób z niepełnosprawnością intelektualną, tworzenia warunków przestrzegania wobec nich praw człowieka, prowadzenia ich ku aktywnemu uczestnictwu w życiu społecznym oraz wspieranie ich rodzin"(www.psouu.gda.pl).

\section{Placówki prowadzone przez PSOUU koło w Gdańsku i realizowane wieloletnie programy jako przykłady całożyciowego wspierania ${ }^{2}$}

1) w odniesieniu do dzieci najmłodszych:

Ośrodek Wczesnej Interwencji i Wspomagania Rozwoju (OWIiR) istnieje od 1989 roku i jest najstarszą placówką, powołaną jeszcze w strukturach Towarzystwa Przyjaciół Dzieci. Pełni funkcję diagnostyczno-konsultacyjno-terapeutyczną względem dzieci w wieku od od urodzenia do 7 lat i dłużej (do momentu rozpoczęcia nauki w szkole podstawowej) i ich rodziców. Oferta palcówki adresowana jest do dzieci niepełnosprawnych intelektualnie, o opóźnionym rozwoju psychoruchowym oraz zagrożonych pojawieniem niepełnosprawności rozwojowych w przyszłości i obejmuje wczesną diagnozę kondycji fizycznej i psychicznej dziecka, indywidualną terapię, różne formy stymulowania rozwoju oraz psychologiczne wsparcie dla rodziców, a także możliwość skorzystania z konsultacji róż-

2 Działalność PSOUU koło w Gdańsku przedstawiona została zgodnie z danymi zamieszczonymi na stronie internetowej organizacji www.psouu.gda.pl oraz na podstawie wiedzy i doświadczenia autorki artykułu, pełniącej do ponad 10 lat rolę sekretarza Zarządu gdańskiego koła. 
nych specjalistów. Dla małych dzieci OWIiR proponuje indywidualne konsultacje oraz zajęcia grupowe: Grupa „Pierwszy Krok” (nauka separowania się od rodziców i nawiązywania kontaktów z rówieśnikami), Grupa prowadzona metodą Weroniki Sherborne, Grupy przedszkolne, Grupy muzyczne, Grypy ogólnorozwojowe, Grupy plastyczne z elementami terapii ręki. Dla rodziców OWIiR prowadzi różne formy pomocy psychologicznej, w tym: indywidualne konsultacje i indywidualne wsparcie terapeutyczne, grupy wsparcia, warsztaty umiejętności wychowawczych, domowy videotrening komunikacji. Dodatkowo w OWIiR istnieje możliwość wypożyczenia do domu książek i zabawek dydaktycznych. Aktualnie w OWIiR zatrudnionych jest 38 osób wysoko wyspecjalizowanej kadry, w tym lekarze rehabilitacji i neurologii, pedagodzy specjalni, logopedzi, psycholodzy, fizjoterapeuci. Średnio w placówce pomoc uzyskuje 1200 dzieci rocznie. OWIiR realizuje kontrakty zawarte z Pomorskim Oddziałem Narodowego Funduszu Zdrowia.

Dopełnieniem wsparcia małego dziecka i jego rodziny jest działalność Poradni Wspomagania Rozwoju Dziecka „Po drodze” (PWRD) - powstałej w 2006 roku niepublicznej placówki oświatowej. Specjaliści PWRD obejmują opieką dzieci, które w swoim młodym wieku wymagają monitorowania i stymulowania nieharmonijnego rozwoju, oraz ich rodziny, wspierając ich kompetencje wychowawcze. Działania PWRD, czyli zatrudnionych tam pedagogów, psychologów i logopedów, ukierunkowane są na zmaksymalizowanie szans dzieci na ich efektywne funkcjonowanie w systemie edukacji, także wspieranie placówek przedszkolnych i szkolnych w zaplanowaniu odpowiedniej dla nich opieki i nauki. Pomagają także rodzicom $w$ wyborze najlepszej formy kształcenia ich dzieci, tj.: odpowiedniej szkoły specjalnej, integracyjnej lub ogólnodostępnej.

2) w odniesieniu do dzieci i młodzieży objętych obowiązkiem szkolnym i obowiązkiem nauki:

Część podopiecznych OWIiW oraz PWRD rozpoczyna realizację swojego obowiązku szkolnego w tzw. środowisku otwartym, są jednak dzieci, które korzystają z oferty kolejnej placówki prowadzonej przez PSOUU koło w Gdańsku, a więc Ośrodka Rewalidacyjno-Edukacyjno-Wychowawczego (OREW). W tej niepublicznej placówce oświatowej, zarejestrowanej w 1996 roku, dzieci (już od 5 roku życia) i młodzież (do 25 roku życia) z głębokim i głębszym upośledzeniem umysłowym oraz z wielorakimi, sprzężonymi niepełnosprawnościami, realizują swój obowiązek szkolny i obowiązek nauki. Pod kierunkiem pedagogów specjalnych, terapeutów zajęciowych, rehabilitantów ruchowych, fizjoterapeutów, nauczycieli komunikacji, logopedów wychowankowie mają szanse na wszechstronny rozwój wspomagany przez integralnie pojmowane kształcenie i nauczanie konkretnych umiejętności na miarę indywidualnych możliwości i predyspozycji, wychowanie, rehabilitacje i terapie. Wychowankowie uczą się więc funkcjonowa- 
nia w środowisku, komunikacji (także alternatywnej), rozwijają się twórczo i aktywnie poznają świat. Rodzicom swoich wychowanków OREW oferuje: wsparcie psychologiczne, poradnictwo socjalne (w OREW zatrudniony jest pracownik socjalny) oraz życiowe (ostatnio wzbogacając swoją ofertę o wspieranie rodziców w wychowaniu seksualnym ich dzieci), informacje, konsultacje i instruktaż w odniesieniu do pracy z dziećmi, co dotyczy nie tylko nauczania i wychowania, ale także pielęgnacji i treningów czystości (w OREW zatrudniona jest pielęgniarka) oraz uzyskania natychmiastowej pomocy medycznej w sytuacji nagłego pogorszenia się stanu zdrowia dziecka (dzięki stałej współpracy z lekarzem dziecięcego hospicjum). Bardzo ważną „usługą”, jaką świadczy OREW jest możliwość pozostawienia dzieci pod opieką specjalistów na 9 godzin dziennie, więc istnieje możliwość podjęcia przez rodziców pracy zawodowej, czemu sprzyja także zapewnienie wychowankom opieki i rekreacji w dni wolne od zajęć dydaktycznych (np. $\mathrm{w}$ czasie ferii i wakacji szkolnych $\mathrm{w}$ postaci półkolonii) oraz podczas godzin popołudniowych (zajęcia świetlicowe). OREW intensywnie rozwija się - w roku 1996 placówka zapewniała 20 miejsc i zatrudniała 9 pracowników merytorycznych, aktualnie swoją specjalistyczną ofertą OREW obejmuje 69 wychowanków, którzy wraz ze swoimi rodzicami, otrzymują wsparcie od 61 pracowników.

3) w odniesieniu do osób dorosłych:

Po tzw. okresie szkolnym podopieczni PSOUU koło w Gdańsku nie pozostają jednak bez możliwości korzystania z dalszego wsparcia specjalistycznych placówek prowadzonych przez Stowarzyszenie. Tu oferowana jest pomoc w dwóch placówkach, w zależności od możliwości intelektualnych i funkcjonalnych osób niepełnosprawnych. Jedną z nich jest Środowiskowy Dom Samopomocy (ŚDS), przeznaczony docelowo dla absolwentów OREWu. Funkcjonująca od 1999 roku placówka jest dziennym ośrodkiem wsparcia dla 23 dorosłych osób z głęboką niepełnosprawnością intelektualną. Celem ŚDS jest rozwijanie i podtrzymywanie umiejętności niezbędnych do samodzielności w życiu, kształtowanie umiejętności społecznych i interpersonalnych, zapobieganie izolacji i wykluczeniu społecznemu uczestników zajęć i ich rodzin. Realizowany program aktywizacji społecznej wspierany jest działaniami rehabilitacyjnymi, terapią psychologiczną, logopedyczną, działaniami ukierunkowanymi na wykonywanie konkretnych czynności pracy pod kierunkiem 7 terapeutów.

Druga placówka to Warsztat Terapii Zajęciowej (WTZ), przeznaczony w większości dla osób dorosłych, niepełnosprawnych intelektualnie w stopniu umiarkowanym i znacznym, korzystających do tej pory z oferty edukacyjnej świadczonej przez publiczne lub niepubliczne szkoły ogólnodostępne, integracyjne lub specjalne. Z usług WTZu mogą skorzystać osoby z niepełnosprawnością intelektualną, w stosunku do których orzeczono niezdolność do pracy, a które kwalifikują się do rehabilitacji w formie terapii zajęciowej. WTZ powstał w 1995 roku, jako placówka 
rehabilitacji zawodowej i społecznej dla 55 uczestników, realizujących indywidualne programy rozwoju i terapii w 11 pracowniach w następujących zakresach: usprawniania i doskonalenia sprawności ruchowej pozwalającej na uzyskanie niezależności w zaspakajaniu podstawowych potrzeb życia codziennego; kształtowania umiejętności prawidłowego zachowania się w kontaktach międzyludzkich, skutecznego komunikowania się w miejscach użyteczności publicznej, bezpiecznego i celowego poruszania się po mieście oraz podnoszenie samodzielności w korzystaniu ze środków komunikacji miejskiej; rozwijania zainteresowań i uzdolnień, poszerzania wiedzy i doświadczeń życiowych, wzbogacania aktywnych form spędzania czasu wolnego; zapewnianie możliwości podejmowania przez uczestników WTZ decyzji w sprawie jakości swojego życia i potrzebnej pomocy. Jednak nadrzędnym celem WTZu jest przygotowanie uczestników do zatrudnienia na otwartym lub chronionym rynku pracy, co także potwierdza główna idea WTZu: rozwój, godne życie, przekraczanie niemożliwych i wyruszanie w świat pracy zawodowej. Zadania aktywizujące do przyszłej pracy, nabywając przy tym umiejętności wykonywania konkretnych czynności, uczestnicy WTZ realizują w pracowniach, w tym: Papieru Czerpanego i Małej Poligrafii, Plastycznej, Krawieckiej i Wyrobu Świec, Witrażu i Malowania na Szkle, Stolarskiej, Ogrodniczo-Porządkowej, Gospodarczo-Porządkowej, Gastronomicznej (w Kuchni Dydaktycznej).

4) w odniesieniu do aktywizacji zawodowej:

WTZ intensywnie współpracuje z Biurem Integracji Zawodowej Osób Niepełnosprawnych (BIZON), które powstało w 2006 roku. BIZON zajmuje się tworzeniem warunków do aktywizacji zawodowej osób z niepełnosprawnością intelektualną, poprzez kompleksową usługę wspomagania w zatrudnieniu, rozpoczynając od udzielania konsultacji i poradnictwa psychologiczno-zawodowego dla osób niepełnosprawnych, ich rodziców i opiekunów. Prowadzi swoją działalność w formie projektów aktywizacji zawodowej opartych o ideę zatrudnienia wspomaganego, którego siła i skuteczność zasadza się na bardzo prostym pomyśle: asystowania osobie z niepełnosprawnością w znalezieniu i utrzymaniu zatrudnienia dzięki indywidualnie zaplanowanemu wsparciu. Kluczową rolę $\mathrm{w}$ tym wsparciu odgrywa trener pracy, który asystuje osobie z niepełnosprawnością $w$ poszukiwaniu pracy, prowadzi szkolenie $\mathrm{w}$ docieraniu do miejsca pracy, przyuczenie do wykonywania pracy na określonym stanowisku, dokonuje bieżącej i okresowej oceny możliwości; przyjmuje na siebie rolę rzecznika osoby niepełnosprawnej i stanowi ogniwo pośredniczące między pracownikiem a pracodawcą. Dzięki pomocy BIZONu osoby niepełnosprawne intelektualnie w stopniu umiarkowanym i znacznym podejmują pracę jako osoby sprzątające, pomagające w kuchni, wykonujące proste prace biurowe. 
Zupełnie nowym przedsięwzięciem PSOUU koło w Gdańsku jest powołanie we wrześniu 2014 roku Niepublicznej Szkoły Przysposabiającej do Pracy (NSPP) dla uczniów z upośledzeniem umysłowym $\mathrm{w}$ stopniu umiarkowanym i znacznym oraz z niepełnosprawnościami sprzężonymi. Program edukacyjny ww. Szkoły zakłada przygotowanie młodzieży do wykonywania, indywidualnie i zespołowo, różnych prac mających na celu zaspokajanie potrzeb własnych i otoczenia, w tym wykonywanie usług na rzecz placówki: prace porządkowe, przygotowywanie menu na imprezy szkolne i obsługa kawiarenki, wytwarzanie wytworów (prac plastyczno-technicznych) z przeznaczeniem na wystrój i promocję Szkoły. Celem nauczania jest kształtowanie u uczniów umiejętności posługiwania się narzędziami, maszynami i urządzeniami oraz opanowanie prostych umiejętności i czynności pracy na zajęciach warsztatowych prowadzonych w szkolnych pracowniach lub poza nią (jeżeli będzie to możliwe). W szkole realizowany jest autorski program "Jesteśmy pomocni", umożliwiający przygotowanie uczniów niepełnosprawnych do aktywności przez pracę, w szczególności w modułach: gospodarstwo domowe i zajęcia kulinarne, prace porządkowe, prace biurowe, rękodzieło artystyczne. Aktualnie do NSPP uczęszcza 14 uczniów.

5) w odniesieniu do czasu wolnego, rozwijania zainteresowań i włączania się w życie kulturowe:

Oprócz pracy ważną rolę w życiu każdego człowieka odgrywa także czas przeznaczony na relaks, rozwój zainteresowań, twórczy odpoczynek. Osoby z głębszą i głęboką niepełnosprawnością intelektualną i w tym należy wspomóc. Od 1995 roku w strukturach PSOUU koło w Gdańsku działa Orkiestra Vita Activa. Orkiestra to oryginalny, artystycznie odrębny zespół, oferujący starannie wybraną muzykę w profesjonalnym wykonaniu - wśród 40 członków orkiestry są dorosłe osoby z niepełnosprawnością intelektualną, ich rodzice oraz wolontariusze. Próby orkiestry odbywają się popołudniami trzy lub cztery razy w tygodniu. Orkiestra gra na instrumentach perkusyjnych melodycznych i niemelodycznych. Grupę instrumentów melodycznych stanowią: grupa dzwonków (sopranowe, altowe), grupa metalofonów (altowe, basowe), grupa ksylofonów (sopranowe, altowe, basowe), oraz sztabki kontrabasowe. Dopełnienie brzmienia dają strojone kotły. Orkiestra używa około 50 instrumentów niemelodycznych: różnej wielkości bębny, talerze, różne odmiany instrumentów kolorystycznych (guiro, kabasa, tempelbloki, china bars, crotale, klawesy, i wiele innych) często egzotycznego pochodzenia. Instrumentarium perkusyjne dopełniane jest instrumentami klasycznymi: kontrabasy, trąbka, sakshorn, tuba, harfa, cytra i elektronicznymi. Rozpiętość brzmienia porównywalna jest do skali orkiestry symfonicznej a dynamika brzmienia i możliwość jej znacznego różnicowania (od ppp do ff) pozwala grać $\mathrm{w}$ stosunkowo dużych salach koncertowych z zachowaniem cech interpretacyj- 
nych wykonywanych utworów. Wyrazem sprawności artystycznej zespołu jest repertuar, na który składają się arcydzieła światowej kultury muzycznej, w tym muzyka gdańska. Orkiestra koncertuje na zaproszenie organizacji non profit, urzędów, firm, osób prywatnych. Koncerty orkiestry mają charakter tradycyjny, zbliżony w konwencji do koncertów orkiestr symfonicznych. Najczęściej orkiestra występuje podczas różnego rodzaju uroczystości, dopełniając muzyką konferencje naukowe, sympozja, festiwale, przeglądy, gale wręczania nagród nadając im stosowną artystyczną oprawę. Na dzień dzisiejszy dorobek orkiestry to: 230 koncertów, około 40000 słuchaczy, 56 miast, 7 międzynarodowych podróży. Jednak poza celami artystycznymi celem Orkiestry jest także integracja środowiska osób wychowujących i opiekujących się osobami dorosłymi z niepełnosprawnością intelektualną (poprzez próby), a także kształtowanie opinii społecznej na potrzeby i rozumienie tej grupy społecznej.

Z działalnością Orkiestry wiąże się, realizowany od 2008 roku, program edukacji kulturalnej pod nazwą Europejskie Centrum Edukacji Kulturalnej Osób Niepełnosprawnych (ECEKON), w którym dzieci i młodzież uczą się gry na instrumentach, przygotowując się do uczestniczenia, już jako osoby dorosłe, w amatorskim ruchu muzycznym, w tym do działalności w Orkiestrze Vita Activa. Kolejną muzyczna formą aktywności w czasie wolnym dla osób niepełnosprawnych jest możliwość udziału w Zespole Muzycznym „Remont Pomp”, który od 2004 roku łączy we wspólnym graniu osoby z niepełnosprawnością intelektualną, wolontariuszy europejskiego programu EVS oraz muzyków współpracujących ze Stowarzyszeniem. Główną inspiracją dla zespołu jest muzyka etniczna z naciskiem na bogactwo muzyki afrykańskiej. Zespół odkrywa przestrzenie muzyki eksperymentalnej grając na przedmiotach na co dzień nie kojarzonych z muzyką. "Remont Pomp" wykonuje wyłącznie program autorski. Największym dokonaniem zespołu jest płyta nagrana wspólnie ze znanymi muzykami jazzowymi Mikołajem Trzaską i Mikiem Majkowskim pt. „Złota Platyna”, której premiera miała miejsce w 2012 roku.

Odmienną formą działalności artystycznej osób z niepełnosprawnością intelektualną to twórczość plastyczna. W strukturach PSOUU koło w Gdańsku w 1995 roku powołano Galerię Świętojańską, która stała się pierwszą w Polsce placówką kultury promującą twórczość plastyczną artystów z niepełnosprawnością intelektualną i pierwszą w Polsce galerią sztuki nurtu „art brut”. Przez 18 lat istnienia przygotowała ponad 200 wystaw prac osób niepełnosprawnych w swojej siedzibie i w takich prestiżowych miejscach jak Państwowa Galeria Sztuki w Sopocie, Muzeum Narodowe w Gdańsku, Oddział Sztuki Współczesnej w Pałacu Opatów w Oliwie, Akademia Sztuk Pięknych w Gdańsku, w galeriach Bydgoszczy, Krakowa, Zielonej Góry, Płocka oraz w siedzibie Urzędu Miasta w Jerozolimie. Galeria prezentuje prace artystów zarówno z terenu całej Polski, jak i zza 
granicy. By propagować i promować artystów z niepełnosprawnością intelektualną członkowie Stowarzyszenia aktywnie włączają się w Międzynarodowe Spotkania z Twórczym Życiem Osób z Niepełnosprawnością Intelektualną „Świat Mało Znany", w formie festiwalu artystycznego, który od 1993 roku miał już 11 edycji. Organizatorzy festiwalu opierają swe działania na przekonaniu, że publiczne prezentowanie dorobku artystycznego osób z niepełnosprawnością, wspieranych w procesie twórczym przez zawodowych artystów, instruktorów i wolontariuszy, przyczynia się do tego, że ten "mało znany świat” ich życia staje się „Światem poznanym", a tym samym światem dobrze rozumianym". Festiwal na stałe wrósł w kalendarz imprez miejskich w Gdańsku. Od roku dwutysięcznego odbywa się pod auspicjami Europejskiego Ruchu na Rzecz Różnorodności i Zrozumienia „Karawana 2000”.

6) w odniesieniu do osiągania samodzielności w dorosłym życiu:

Człowiek dorosły to osoba, która, między innymi, osiągnęła swoją dojrzałość biologiczną i fizyczną oraz określony wiek życia (www.wikipedia.pl), to osoba gotowa do podjęcia pracy zarobkowej, a także do odseparowania się od rodziców i rozpoczęcia prowadzenia samodzielnego gospodarstwa domowego. Jedną z form pomocy w osiąganiu dorosłości przez osoby z niepełnosprawnością intelektualną jest podjęta przez gdańskie koło PSOUU inicjatywa pod nazwą Zespół Mieszkań Wspomaganych (ZWM). W wyniku działań rodziców dorosłych dzieci z niepełnosprawnością intelektualną w 2007 roku na jednym z gdańskich osiedli został wybudowany dom (blok), w którym znajduje się 17 indywidualnych mieszkań. Mieszkania te są usytuowane wokól jednej klatki w 3-kondygnacyjnym budynku. Dorosła osoba niepełnosprawna ma do swojej dyspozycji jeden (lub dwa mniejsze) pokój, aneks kuchenny i łazienkę. Dodatkowo na każdym poziomie domu znajduje się kuchnia i duży pokój przeznaczony do użytkowania wszystkich mieszkańców danej kondygnacji. Parter budynku, przystosowany jest dla poruszających się na wózku i mieszkają tam osoby o sprzężonych niepełnosprawnościach. Na najniższej kondygnacji budynku znajduje się jedno mieszkanie, które pełni rolę mieszkania chronionego, a w szczególnych sytuacjach - pogotowia mieszkaniowego oraz pomieszczenia administracyjno-biurowe. Mieszkańcy w ciągu dnia przebywają poza miejscem zamieszkania uczestnicząc w WTZ, przebywając w ŚDS lub wykonując pracę zawodową. Popołudnia oraz weekendy spędzają we własnym domu i w sposób, w jaki sami sobie wybierają. W czynnościach życia codziennego każdego mieszkańca wspomaga wykwalifikowana kadra, w ilości 7 osób. Wszystkie działania mają charakter indywidualnego wsparcia, które dostosowane jest do potrzeb każdego z mieszkańców. $\mathrm{W}$ zakres wsparcia wchodzi: asystentura $\mathrm{w}$ samodzielnym prowadzeniu domu ( $w$ tym wspieranie mieszkańca $\mathrm{w}$ umiejętności utrzymania porządku w najbliż- 
szym otoczeniu, utrzymaniu higieny osobistej, praniu, prasowaniu, przygotowywaniu posiłków, planowaniu i dokonywaniu zakupów, obsługi pralki automatycznej, żelazka); wspieranie mieszkańca w przygotowywaniu posiłków (w tym wsparcie w samodzielnym przygotowywaniu prostych posiłków, takich jak: śniadania i kolacja, wdrażanie do coraz bardziej skomplikowanych zadań związanych z przygotowaniem złożonych posiłków, umiejętność przygotowania stołu do posiłku, posprzątania po posiłku, obsługi zmywarki, kuchenki elektrycznej); prowadzenie treningu ekonomicznego ( $w$ tym asystowanie mieszkańcowi podczas realizacji opłat, wsparcie w planowaniu wydatków na dzień, tydzień, miesiąc, prowadzeniu systemu systematycznego oszczędzania oraz planowaniu budżetu, dokonywaniu zakupów, płaceniu za nie i odbieraniu reszty z paragonem); wspieranie mieszkańca $w$ korzystaniu $z$ usług różnych urzędów ( $w$ tym pomoc w wypełnianiu prostych dokumentów urzędowych, pisanie pism, wsparcie w załatwianiu bieżących spraw urzędowych); organizacja oraz spędzanie czasu wolnego (w tym rozwijanie zainteresowań, poszerzanie ich zakresu, propagowanie i umożliwianie aktywnego stylu życia); nawiązywanie i utrzymywanie kontaktów społecznych (w tym wspieranie w budowaniu świadomości własnych granic, szacunku dla nich, komunikowaniu ich, słuchaniu innych, ćwiczenie umiejętności nawiązywania i podtrzymywania relacji).

7) w odniesieniu do korzystania z pomocy z zewnątrz:

Dużym wsparciem dla rodziców osób niepełnosprawnych jest korzystanie z pomocy wolontariuszy w różnych czynnościach dnia codziennego. Program "Starszy Brat-Starsza Siostra” oraz „Wolontariat Międzynarodowy” to dwa integralnie ze sobą połączone programy realizowane przez PSOUU koło w Gdańsku od 1999 roku. Istotą programu Starszy Brat-Starsza Siostra jest tworzenie indywidualnych związków koleżeńskich i przyjaźni pomiędzy osobami z niepełnosprawnością intelektualną, a pełnosprawną młodzieżą lub młodymi dorosłymi. Wolontariusze ze swoimi programowymi braćmi i siostrami, zobowiązują się do spotkań w ich środowiskach domowych przez co najmniej rok. Wspólnie podejmują aktywności, od zwykłego bycia razem, poprzez rozwój zainteresowań i uczestnictwo w wydarzeniach kulturalnych, sportowych aż po różne formy szeroko rozumianej integracji społecznej. Rokrocznie Stowarzyszenie zaprasza do współpracy około 12 młodych ludzi z Europy, by przez kilka miesięcy pracowali oni społecznie biorąc udział $\mathrm{w}$ działalności różnych placówek $\mathrm{i}$ w realizacji wielu programów.

8) w odniesieniu do prowadzonej działalności informacyjnej:

W podobny sposób, czyli prowadząc różnego rodzaju placówki i realizując wieloletnie programy, działają wszystkie koła PSOUU na terenie naszego kraju, 
oczywiście dostosowując się do potrzeb lokalnego środowiska i żyjących tam rodzin wychowujących osoby z niepełnosprawnością intelektualną. Ale działalność PSOUU na rzecz osób z niepełnosprawnością intelektualną to także organizacje sympozjów, szkoleń i konferencji, wydawanie kwartalnika „Społeczeństwo dla Wszystkich", publikacja broszur, książek oraz filmów szkoleniowych dla profesjonalistów i rodziców. Na każdym szczeblu działalności PSOUU reprezentuje interesy osób z niepełnosprawnością intelektualną i ich rodzin, także poprzez ruch self - adwokatów (www.psouu.org.pl). Współtworzy ekspertyzy dotyczące różnych aspektów niepełnosprawności, a także występuje z inicjatywami zmian $\mathrm{w}$ prawie. Tym samym informuje społeczeństwo, czego potrzebują osoby niepełnosprawne i ich rodzice, oraz, że przy zapewnieniu im stosownego wsparcia mogą prowadzić godne i jakościowo udane życie.

\section{Bibliografia}

Dykcik W. (2010), Tendencje rozwoju pedagogiki specjalnej. Osiagnięcia naukowe i praktyka, Wydawnictwo Naukowe PTP, Poznań.

Dykcik W. (2010), Odpowiedzialność cztowieka w kontekście indywidualnym i spotecznym, Wydawnictwo Naukowe PTP, Poznań.

Dykcik W. (2005), Pedagogika specjalna wobec aktualnych sytuacji i problemów osób niepetnosprawnych, Wydawnictwo Naukowe PTP, Poznań.

ICD-10 (2009), Międzynarodowa Statystyczna Klasyfikacja Chorób i Problemów Zdrowotnych (rewizja dziesiąta), t. 1, Wydawnictwo WHO.

Jagieła J. (2007), Relacje w rodzinie a szkoła, Wydawnictwo Rubikon, Kraków.

Kościelska M. (2000), Oblicza upośledzenia, Wydawnictwo PAN, Warszawa.

Krause A. (2000), Integracyjne złudzenia ponowoczesności, Oficyna Wydawnicza „Impuls”, Kraków.

Lausch-Żuk J. (2001), Pedagogika osób z umiarkowanym, znacznym i głębokim upośledzeniem umystowym [w:] Pedagogika specjalna, red. W. Dykcik, Wydawnictwo UAM, Poznań.

Pisula E. (1998), Psychologiczne problemy rodziców dzieci z zaburzeniami rozwoju, Wydawnictwo UW, Warszawa.

Tylewska-Nowak B. (2010), Umiarkowana i znaczna niepetnosprawność intelektualna [w:] O co pytają rodzice dzieci z niepetnosprawnościa?, red. A. Jakoniuk-Dialo, H. Kubiak, Wydawnictwo Difin SA, Warszawa.

www.psouu.gda.pl

www.psouu.org.pl

www.wikipedia.pl 